\title{
Climate change, ecosystems and smallholder agriculture in Central America: an introduction to the special issue
}

\author{
Pablo Imbach ${ }^{1,2} \cdot$ Megan Beardsley $^{1}$. \\ Claudia Bouroncle $^{1}$ - Claudia Medellin ${ }^{1}$. \\ Peter Läderach $^{2}$ • Hugo Hidalgo ${ }^{3,4}$ - Eric Alfaro ${ }^{3,4,5}$. \\ Jacob Van Etten ${ }^{6}$ - Robert Allan ${ }^{7}$ - Debbie Hemming ${ }^{7,8}$ • \\ Roger Stone ${ }^{9}$ Lee Hannah ${ }^{10}$ - Camila I. Donatti ${ }^{10}$
}

Received: 6 December 2016 / Accepted: 28 January 2017 /Published online: 28 February 2017

(C) Springer Science+Business Media Dordrecht 2017

\section{Introduction}

Central America is one of the regions most exposed to climate change (Giorgi 2006). A narrow isthmus between the Pacific Ocean and the Caribbean Sea, it is strongly affected by droughts,

This article is part of a Special Issue on "Climate change impacts on ecosystems, agriculture and smallholder farmers in Central America" edited by Camila I. Donatti and Lee Hannah.

Lee Hannah

lhannah@conservation.org

1 Climate Change Program, Tropical Agricultural Research and Higher Education Centre (CATIE), Turrialba, Cartago 30501, Costa Rica

2 Climate Change, Agriculture and Food Security Program (CCAFS), International Centre for Tropical Agriculture (CIAT), Cali, Colombia

3 Centro de Investigaciones Geofísicas, Universidad de Costa Rica, San José, Costa Rica

4 Escuela de Física, Universidad de Costa Rica, San José, Costa Rica

5 Centro de Investigación en Ciencias del Mar y Limnología, Universidad de Costa Rica, San José, Costa Rica

6 Bioversity International, Turrialba, Cartago 30501, Costa Rica

7 Met Office Hadley Centre, FitzRoy Road, Exeter EX1 3PB, UK

8 Birmingham Institute of Forest Research, Birmingham University, Edgbaston, Birmingham B15 2TT, UK

9 International Centre for Applied Climate Sciences, University of Southern Queensland, Toowoomba, QLD 4350, Australia

10 The Betty and Gordon Moore Center for Science, Conservation International, Arlington, VA 22202, USA 
hurricanes and the El Niño-southern oscillation (ENSO) phenomena (CEPAL 2011). As a result, three countries in the region rank in the top 10 of the Global Climate Risk Index (Kreft and Eckstien 2013) based on the impacts of extreme weather events between 1993 and 2012.

Much of the regional economy is based on agriculture. In Guatemala, Honduras and Nicaragua, more than two thirds of the population depends on agriculture. This agricultural base is often intimately tied to ecosystems, especially in diverse farming systems of smallholders. But it is increasingly threatened by climate variability and change (Bouroncle et al. 2016; Baca et al. 2014), which are inducing changes in areas suitable for crops and leading to high yield variability. Storms, floods and droughts have had the greatest impacts on agriculture in Central America over the last century (Guha-Sapir et al. 2014).

This special issue addresses the adaptation challenges facing smallholders, ecosystems and ecosystem services in the region. In this introduction, we review the literature on regional climate and its drivers, climate change projections, impacts on agriculture and ecosystems, and information management for adaptation in the region. Short descriptions of the special issue contributions are provided throughout the text.

\section{Weather and climate in Central America}

The topography of Central America is a complex of coasts, plains and high mountains that determine its climate (Taylor and Alfaro 2005). The main topographic feature of the region is the Central American Cordillera on the Pacific coast with plains running to the Atlantic. Precipitation in the region is seasonal, controlled by the Inter-Tropical Convergence Zone (ITCZ) and the North Atlantic trade winds interacting with the Cordillera (Nieuwolt 1977). A dry arc, the corredor seco, starts in the north of Costa Rica and extends into Nicaragua, Honduras and Guatemala on the Pacific side and also includes a portion of the central Pacific coast of Panama (known as arco seco).

The region has a wet season from June to September which is punctuated by a short dry spell, or canicula, and an extended dry season between November and May. On the Caribbean coasts of Honduras, Nicaragua, Costa Rica and Panama, rainfall occurs throughout the year, especially from October to December and, to a lesser extent, between January and April (Magaña et al. 1999). Inter-annual variability is high for both the Caribbean and Pacific watersheds with near decadal cycles of extreme precipitation (Hastenrath and Polzin 2013).

Over most of Central America the bimodal rainfall distribution determines the onset of the rainy season and the length and dryness of the canicula (dry period), which sets the agricultural calendar. The historical record indicates that when the sea surface temperature (SST) of the tropical Atlantic is warmer than usual, early-season rainfall is above average over much of Central America, while when SST is cooler the early-season rainfall is below average (Alfaro 2007a). Moreover, when the SST of the Pacific is warmer than usual and the Atlantic cooler than usual, late-season rainfall on the Pacific slopes of the Central America Cordillera is below average, and the reverse is also true.

\section{What drives weather and climate in Central America?}

The dominant large-scale influence on weather and climate in Central America is the subtropical high of the north Atlantic, a semi-permanent system over North America (Taylor and Alfaro 2005; Amador et al. 2006). During winter (December-March), it spreads over North America and the cold ocean, causing the dry northeast trade winds that bring little moisture to 
Central America. As the year progresses, the high moves offshore, the oceans warm and the winds weaken, bringing more moisture to the region. Other drivers are (a) the migration of the ITCZ, which affects the Pacific side of southern Central America (Hidalgo et al. 2015); (b) intrusions of polar fronts, which modify the dry winter and early summer climates of the northern part of the region (Zárate-Hernández 2013); and (c) westward-moving tropical disturbances in the summer, which can bring torrential rain (Serra et al. 2010).

An annual cycle, driven by the latitudinal migration of the ITCZ, the seasonal variation of solar radiation, and the interaction of low-altitude winds with local orography, accounts for $72 \%$ of the variance in regional precipitation (Alfaro 2002). The inter-annual and decadal variability in Central American precipitation is related to the surface temperatures of the tropical Atlantic and Pacific oceans (Steinhoff et al. 2015). The wettest years occur when the surface temperature of the tropical Atlantic is warmer and the eastern tropical Pacific is cooler than usual (the ENSO phenomenon), and the driest tend to be observed when the tropical Atlantic is cooler and the tropical Pacific is warmer (Steinhoff et al. 2015). Improved ENSO indices (such as the normalized difference between Niño3.4 and Tropical North Atlantic indexes, Hidalgo et al. 2016) are highly correlated with precipitation in most of Central America, suggesting that the difference in SST between the Pacific and the Caribbean/ Atlantic might be used to forecast precipitation in the region.

Hurricanes, especially between June and November, are common in the northern Caribbean and the Gulf of Mexico. An average of eight hurricanes occur each year, but the frequency increases when the tropical North Atlantic is warm, and decreases during the ENSO warm phase (El Niño) (Alfaro 2007b).

\section{Trends and projected impacts of climate change}

The Central American climate generally warmed during 1950-2000 (Malhi and Wright 2004) with increasing incidence of extreme warm maxima and minima and decreased extreme low temperatures (Aguilar et al. 2005). Trends in precipitation vary between studies (Malhi and Wright 2004; Aguilar et al. 2005; Neelin et al. 2006) due to high variability in precipitation across the region (Aguilar et al. 2005; Hastenrath and Polzin 2013). In this issue, Hidalgo et al. (2016) used temperature data from stations and gridded datasets to generate a high-resolution dataset for Central America from 1970 to 1999, and found that there were significant warming trends in most of the region, and cooling trends in central Honduras and western Panama.

Global Climate and Earth System Models (ESMs) show that Central America is projected to become distinctly drier in the future (Neelin et al. 2006), caused by higher temperatures and lower precipitation (Biasutti et al. 2012). Increased extreme precipitation during tropical cyclones is also expected (IPCC 2013). ESMs agree on higher temperatures over Central America and reduced precipitation for northern parts of the region. However, the rainfall signal over Southern Nicaragua and Costa Rica is uncertain and certainty increases for positive trends in Panama (Imbach 2012; Hidalgo et al. 2016). ESM simulations suggest that there will be less rainfall during the wet season (Biasutti et al. 2012), particularly in the north of the region where the canicula will be longer and drier (Rauscher et al. 2008). More extreme rainfall events and longer dry spells in the wet season are also projected in the northern part of the region (Biasutti et al. 2012; Nakaegawa et al. 2013b). Although these models generally represent current ENSO precipitation anomalies well, future trends are less certain, except that ENSO events will be more frequent (Steinhoff et al. 2015). 


\section{Forecasts in Central America}

Fallas and Alfaro (2012a) developed predictive schemes of precipitation for the Pacific and Caribbean slopes of the Central America Cordillera. They used indices from the preceding bimester to predict the current season. They found that most of the variability in Central America climate could be explained by the ENSO and the Atlantic Multi-decadal Oscillation (AMO) indices. Fallas and Alfaro (2012b) used tropical Pacific SST in the previous trimester to predict late-season precipitation on the Central America Pacific slopes. Maldonado et al. (2013) found that the July tropical Pacific SST captures the ENSO and AMO phenomenon to predict late-season precipitation over Costa Rica. If forecasts based on these relations were made available to farmers, they would be able to support key on planting dates and what crops to grow.

Alfaro (2000) found that ENSO-related indices were positively correlated with surface temperature across all seasons ( $>50 \%$ detection and $<10 \%$ false alarms). At decadal scales, temperatures in Central America were positively correlated with both the Pacific and the Atlantic SSTs. Fallas-López and Alfaro (2014) found that warmer than average SSTs in the positive east equatorial Pacific were associated with warmer land air temperatures. The reverse was also true.

The coarse resolution of global weather and climate observational datasets poorly capture the complexity of Central America topography. Moreover, evaluation of the skill of CMIP5 ESMs showed great uncertainty in the depiction of mean and standard deviation of precipitation (Hidalgo and Alfaro 2014). Although surface temperature showed better results, ESM data should be used with care in Central America.

The performance of a few regional climate models have been assessed for this region (Hernandez et al. 2006; Tourigny and Jones 2009; Karmalkar et al. 2011; Diro et al. 2012; Nakaegawa et al. 2013a; Oglesby et al. 2016); however, there are a limited number of studies with downscaled future climate scenarios (Karmalkar et al. 2011; Nakaegawa et al. 2013b). The potential for improving recommendations for the regional agricultural sector with these research developments in regional seasonal forecasts has been highlighted by García-Solera and Ramirez (2012).

\section{Agriculture in Central America}

The economies of Central American countries have relied on agricultural exports since the early 1900s, focused initially almost exclusively on bananas in the lowlands and coffee at intermediate altitudes. By the late 1940s, sugar, beef and cotton were added to the portfolio, increasing the resilience of national economies (Bulmer-Thomas 1987). In the 1970s, further crops were added, such as temperate vegetables and soft fruits in the highlands, and tropical fruits, such as mangos, melons, and pineapple in lower areas. Oil palm has expanded rapidly in the last decade in lowland areas.

Coffee is the most important export product in Central America, with a value of \$3.70B in 2011, which is more than bananas $(\$ 1.64 \mathrm{~B})$, sugar $(\$ 1.03 \mathrm{~B})$ and palm oil $(\$ 0.68 \mathrm{~B})$ combined (FAO 2012). Maize and beans are the most important food staples. Sugarcane and bananas for export are controlled by large companies, while basic grains and nontraditional products (horticulture or fruits) are grown by smallholder farmers. Coffee is produced both by smallholders and in large plantations. With the raised importance of nontraditional products in the 
export market, many smallholder farms were included into the export economy, interconnecting the two types of agriculture (Krznaric 2006).

Food security mainly depends on maize, rice and beans (Espíndola et al. 2005). Beans are grown throughout the region for domestic consumption, but commercially in two locations: eastern Guatemala into El Salvador and from Yoro, Comayagua and Olancho in Honduras through Nueva Segovia to Matagalpa in Nicaragua. Costa Rica and Panama grow beans, but also import it from China. Rice is important in Nicaragua, Costa Rica and Panama, but less so in Guatemala, El Salvador and Honduras. Maize is grown for domestic consumption across Central America, while commercial production roughly coincides with the main bean-growing areas of Nicaragua and Honduras. Maize is grown commercially in northern, southern coast and in the east of Guatemala, and imports from the USA and Mexico complement local production (Banco de Guatemala 2015).

\section{Impacts of climate change on agriculture in Central America}

Agricultural products from the region are sensitive to changes in climate and weather, both in the field and throughout the value chain. Large losses in coffee suitability are projected for the region (Baca et al. 2014; Bunn et al. 2015). Field crops are most sensitive to extreme weather events (McSweeney and Coomes 2011). Pest and diseases affect all crops and are often driven by climatic conditions, for example, when increased temperature shortens the life cycle of pests (CATIE and CCAFS 2014). Climate-driven events such as flooding can also disrupt crop harvest, processing and transport.

Drought impacts the largest number of crops, closely followed by increased precipitation and floods. Woody fruit trees suffer lower impacts relative to subsistence crops (rice, sorghum and beans) that suffer the largest impacts from droughts. Coffee, banana, rice, and highland vegetables are likely to be affected by the largest variety of climate risks such as extreme temperatures or wind damage (CATIE and CCAFS 2014). The results of modeling crop suitability and yield in the region, including possible policy responses, are summarized in this issue in Hannah et al. (2016a).

Higher ambient temperatures speed up the ripening of coffee berries, leading to poorer cup quality. Moreover, high-value arabica coffee, especially the type for lucrative specialty markets, requires lower temperatures than the less valuable robusta coffee. Changes in temperature and rainfall are expected to decrease the area suitable for coffee and effectively move production up the altitudinal gradient to cooler climates (Ovalle-Rivera et al. 2015). At the national scale, Costa Rica, El Salvador, and Nicaragua have the highest percentages of land that will be most affected losing up to $40 \%$ or more in suitability by 2050 (Läderach et al. 2010). Areas currently growing arabica may therefore need to replace it with lower-value robusta coffee, with cattle pasture, or with food crops. In this special issue, a quantification of the impacts of climate change on coffee suitability and on the production of high quality coffee, as well as the identification of an adaptation framework to guide adaptation planning, are presented by Läderach et al. (2016).

The production cycle of coffee is highly dependent on rainfall patterns. Flowering is triggered by the first rains of the rainy season, but if it becomes too dry or too wet, both coffee flowers and fruits may dehisce or not grow to full size. Stunted fruits give smaller, lowquality beans, which fetch lower prices. The incidence of pests and diseases can be also be altered by changes in the seasonal patterns of rainfall (Avelino et al. 2015). Harvesting coffee is 
a major cost of production and erratic cycles of flowering and ripening require additional harvests, which can increase costs. Reduced precipitation could also reduce the amount of water available for post-harvest processing.

High temperatures, especially night temperatures above $18{ }^{\circ} \mathrm{C}$, and increased droughts predicted for the region will reduce growth and damage the reproductive stages of both maize and beans. Therefore, improved soil management will be critical to enhance crop resilience and minimize yield reductions under increased water stress. In Honduras, El Salvador and Nicaragua, and in poor soil simulations, maize yields are expected to decline in more than $15 \%$ by 2025 (Eitzinger et al. 2013). Beans are sensitive to drought stress and to high temperatures, especially high nighttime temperatures, which reduce flowering and thus grain yield. By 2025 , bean production in Central America could be reduced by more than $20 \%$. Nicaragua and Honduras, the main bean-producing countries, can expect yield losses of 14\%. El Salvador will suffer a reduction of $7 \%$, but Guatemala might increase its overall production because of its highlands (Eitzinger et al 2013).

\section{Central American biodiversity and ecosystems}

The MesoAmerica Biodiversity Hotspot harbors an estimated 17,000 plant species, perhaps as many as 5000 of which are endemic (Gentry 1982; DeClerck et al. 2010). The region's mammalian diversity counts 440 species, with 210 species and 3 genera as endemics (Myers et al. 2000; DeClerck et al. 2010). Bird, reptile, amphibian and invertebrate diversity and endemism are also high. These levels of diversity and endemism make the region a high international conservation priority (Myers et al. 2000).

Ecosystems in the region include tropical moist forest, tropical dry forest, montane oakbamboo forest, montane pine-oak forests, high elevation conifer forest and coastal dunes (Olson et al. 2001). Tropical moist and dry forests are the most widespread, but montane forest types are common in most countries. Tropical moist forest extends throughout the region from Guatemala to Panama. In some locations, the composition of this forest has been changed by pre-European civilizations and indigenous peoples, enriching it with species that have practical applications. Dry forests originally extended from southern Mexico to northern Costa Rica (as well as isolates in Panama), but these forests are now highly fragmented and scarcely protected (DeClerck et al. 2010).

Tropical moist forest is sensitive to drought and duration of dry period, which makes climate change a particular concern for forest conservation in the region (Engelbrecht et al. 2007). Montane cloud forests are key sources of water, a function that may become more critical if climate change is characterized by drying in the lowlands. Dry forests are heavily fragmented in part because the difficulties of production in the water-poor corredor seco favor extensive, rather than intensive land uses and because recovery from damage is slow (but not impossible_-see Janzen 1987).

\section{Impacts of climate change on biodiversity and ecosystems}

Climate change has already had profound impacts in the biodiversity and ecosystems of the region, including perhaps the first recorded extinction due to anthropogenic climate change. The golden toad (Incilius periglenes) disappeared from the forests of Monte Verde in Costa 
Rica in 1987. In prior years, the toad was cryptic most months but gathered in large, conspicuous mating aggregations each year. The breeding aggregation consisted of only a few individuals in 1986 and has never been recorded since. Scientists studying the extinction have concluded that it was driven by dry periods associated with climatic change, which allowed an invasive fungal pathogen to reach lethal abundance (Pounds et al. 1999). Other amphibians are also impacted. Frogs in the genus Atelopus are disappearing throughout Central America due to the same climate-linked disease mechanism (Pounds et al. 2006). Pollinator species, which are very important in maintaining crop production in the region, will also be impacted by climate change. In this issue, adaptation strategies to maintain pollinator forest habitats, which can benefit smallholders as climate changes, are presented by Hannah et al. (2016b), and Fung et al. (2016) show a methodology for identifying country-level priority areas for biological corridors and biodiversity conservation areas as climate changes in tropical regions.

Dry tropical forest in parts of the region are showing increases in deciduous species in response to climate change (Enquist and Enquist 2011). The impacts of climate change on cloud forests have major implications for both biodiversity and ecosystem services. Cloud forests in the region have been projected to experience drying and loss due to lifting cloud bases. As surface air temperatures rise due to climate change, models show altitude increases in cloud bases (Still et al. 1999). This raising of cloud base reduces the amount of cloud contact with montane forests, drying the forests and reducing water yield. Cloud bases may also rise due to lack of moisture inputs from the lowlands, owing to deforestation and reduced evapotranspiration (Lawton et al. 2001). The combination of land use change and climate change may therefore have serious consequences for cloud forests and downstream water availability in the region. Previous studies, using biogeography-equilibrium approaches, found reduced leaf area index of ecosystems in the region, indicating a shift to drier vegetation types (Imbach et al. 2012). Results of a Regional Climate Model simulations and its implications for tropical forests in the region are explored in this issue by Lyra et al. (2016), the first regional study to our knowledge that uses dynamic vegetation models.

\section{Climate change information}

Existing climate information products in Central America do not usually include recommendations on farm or ecosystem management (Bouroncle et al 2015). Information products in the region are typically of a general nature without a specific time horizon and do not include information for particular regions or crops (Bouroncle et al 2015). Such lack of information saliency and usability are typical limitations of information products (Lemos et al. 2012). This lack has been overcome, for example, in nearby Caribbean countries through boundary organizations that guide information brokering to understand how sectors experience risks associated to climate (Guido et al. 2016). For the limited but growing number of information products in the region that specifically address agriculture or ecosystems, many lack interdisciplinary approaches (Bouroncle et al. 2015). However, products that provide information to support planting dates and selection of crop varieties now exist in the region (CATIE and CCAFS 2014). This suggests that the situation may improve in the future.

Most of the climate information products do not employ feedback from the demand side and there is a lack of assessments of the impacts that information products might have had on decision making. There are typically weak interactions between data producers in universities and on-farm users in the region, which are common barriers when the scale of information, 
such as that produced in climate change analyses, has broad geographic coverage (Lemos et al. 2012; Mase and Prokopy 2013). Many products are limited by lack of appropriate information scale, use of language not tailored for the end-user, or ineffective mechanisms of information diffusion (Bouroncle et al. 2015). In this issue, Donatti et al. (2016) address these topics by examining the information that policy makers need in order to take action on climate change adaptation in Central America and providing suggestions on how scientific and technical information can be more frequently used in decision making.

\section{Organizations supporting climate change adaptation in the region}

Adaptation for agriculture, such as the implementation of agricultural technology and improvement of extension services, is usually the responsibility of Ministries of Agriculture, while for ecosystems and species the responsible ministries are generally the natural resources management agencies, such as Ministries of Environment. All countries in the region have policies and laws for disaster risk management supporting their initiatives. Private and public associations and extension services are important communication channels in Central America, and sustained funding for their partnerships could increase the potential for successful use of climate information, a task that NGOs are well positioned to lead (CATIE and CCAFS 2014). NGOs developing crop-specific information products are usually related to large-scale farming, for example, the Private Institute for Climate Change Research in Guatemala, which supports sugarcane producers, and BANACLIMA, which supports banana growers in Costa Rica and provides forecasts and alerts for extreme weather events.

There are also bodies that aggregate large numbers of producers such as the Regional Cooperative Program for Technological Development and Modernization of Coffee, which integrates the sector. Farm managers use the information to optimize aerial spraying, use of fertilizers, nematicides and fungicides (see https:/www.corbana.co.cr/categories/banaclima). Similarly, the Guatemalan and Costa Rican National Coffee Associations operate a weather station network to support their farmers (see examples at http://www.icafe.go. $\mathrm{cr} /$ icafe/clima/clima.html and http://meteorologia.anacafe.org/).

Efforts also include participatory early warning systems in Nicaragua, Honduras, El Salvador and Guatemala (CARE-ECHO project, http://care.org.hn/nuestrasiniciativas/vigentes/care-echo-corredor-seco/). There is scant evidence in Central America on the impacts of improved access to cellular telephones and the internet on information use by smallholder farmers. Nevertheless, current cellular coverage does reach remote communities, potentially providing a large number of users access to information that would help their decision-making, and applications such as Cropster specifically target climate change-relevant information. Recent advances in e-learning may also provide distance education for farmers in how to manage climate risk (Stone et al. 2012).

Two mapping contributions to this special issue offer information valuable to these organizations and their adaptation planning and communication activities. Bouroncle et al. (2016) address the adaptive capacity and vulnerability of smallholder agricultural livelihoods in four countries in the region at the municipality level. Holland et al. (2016) present an innovative methodology, applicable in data-poor environments, for mapping the adaptive capacity of smallholder farmers to climate change at the landscape level, using expert knowledge. 


\section{Contents of the special issue}

Against this backdrop, the papers of this special issue explore aspects of climate change, smallholder agriculture and ecosystems. As noted above, these contributions span climate science to climate change biology and agricultural adaptation. Observed climate change is summarized by Hidalgo et al. as an introduction to climate change exposure in the region. Modeling of climate change impacts on agriculture and ecosystems for the region is summarized by Hannah et al., with indications that suitability for multiple key crops in the region may decline. A more in-depth look at one of the most important crops in the region-coffee-is presented by Läderach et al., and reinforces the view that climate change may have negative consequences for agriculture in the region. The finescale interaction of climate change with ecosystem services and smallholder agriculture is addressed by Hannah et al., who suggest that careful strategies to maintain pollinators' forest habitats can benefit smallholders as climate changes. Fung et al. examine conservation planning for climate change and present a map of priorities for biodiversity conservation and biological corridors within an existing protected areas network. The results of a Regional Climate Model simulation and its implications for tropical forests in the region are explored by Lyra et al., while Donatti et al. examine the information policymakers need in order to plan viable climate adaptation responses for Central America. The adaptative capacity of smallholder farmers is addressed in Bouroncle et al., who map adaptive capacity and vulnerability of smallholder agriculture livelihoods in the region, as well as by Holland et al., who present an innovative methodology to assess adaptive capacity in data-poor environments.

Acknowledgements Information included in this review was discussed and presented in the workshop 'Managing climate risks to agriculture in Central America', hosted by IMN of Costa Rica, CRRH, CATIE, Met Office Hadley Centre (UK), CIRAD, CCAFS, CIAT, and WMO. We thank institutions and participants for making the workshop possible. LH and CID were supported by the CASCADE project ("Ecosystem-based Adaptation for Smallholder Subsistence and Coffee Farming Communities in Central America"). This project is part of the International Climate Initiative (ICI). The German Federal Ministry for the Environment, Nature Conservation, Building and Nuclear Safety (BMUB) supports this initiative on the basis of a decision adopted by the German Bundestag. DH and RA were supported by the Joint UK BEIS/Defra Met Office Hadley Centre Climate Programme (GA0110, GA01101). RA thanks the International Centre for Applied Climate Sciences, University of Southern Queensland. PL, JVE and PI work was implemented as part of the CGIAR Research Program on Climate Change, Agriculture and Food Security (CCAFS), which is carried out with support from CGIAR Fund Donors and through bilateral funding agreements. For details please visit https://ccafs.cgiar.org/donors. The views expressed in this document cannot be taken to reflect the official opinions of these organisations.EA and HH also thank the UCR grants 805-B6143 (supported by Vice-official opinions of these organisations.EA and $\mathrm{HH}$ also thank the UCR grants 805-B6143 (supported by Vicepresidency of Research at University of Costa Rica (UCR), CONICIT and MICITT), A9532 (supported by CSUCAASDI), B4227, B0065, B0810, and A4906 (CIGEFI-UCR, PESCTMA). PI received financial support from AC3 project from the International Development Research Centre (IDRC) Canada.

\section{References}

Aguilar E, Peterson TC, Obando PRR et al (2005) Changes in precipitation and temperature extremes in Central America and northern South America, 1961-2003. J Geophys Res 110:1-15. doi:10.1029/2005JD006119

Alfaro EJ (2000) Response of air surface temperatures over Central America to oceanic climate variability indices. Tópicos Meteorológicos y Ocean 7:63-72. doi:10.4067/S0717-71782002030100006

Alfaro E (2002) Some characteristics of the annual precipitation cycle in Central America and their relationships with its surrounding tropical oceans. Tópicos Meteorológicos y Oceanográficos 9(2):88-103 
Alfaro EJ (2007a) Uso del análisis de correlación canónica para la predicción de la precipitación pluvial en Centroamérica. Rev Ing y Compet 9:33-48

Alfaro E (2007b) Escenarios climáticos para temporadas con alto y bajo número de huracanes en el Atlántico. Rev Climatol 7:1-13

Amador JA, Alfaro EJ, Lizano OG et al (2006) Atmospheric forcing of the eastern tropical Pacific: a review. Prog Oceanogr 69:101-142. doi:10.1016/j.pocean.2006.03.007

Avelino J, Cristancho M, Georgiou S et al (2015) The coffee rust crises in Colombia and Central America (20082013): impacts, plausible causes and proposed solutions. Food Sec 7:303-321. doi:10.1007/s12571-015-0446-9

Baca M, Läderach P, Haggar J et al (2014) An integrated framework for assessing vulnerability to climate change and developing adaptation strategies for coffee growing families in mesoamerica. PLoS One. doi:10.1371 /journal.pone.0088463

Banco de Guatemala (2015) Comercio exterior de Guatemala: importaciones y exportaciones

Biasutti M, Sobel AH, Camargo SJ, Creyts TT (2012) Projected changes in the physical climate of the Gulf Coast and Caribbean. Clim Chang 112:819-845. doi:10.1007/s10584-011-0254-y

Bouroncle C, Imbach P, Manrow M (2015) Estado del arte de los productos de información agroclimática en América Central. Technical Report. Turrialba, Costa Rica

Bouroncle C, Imbach P, Rodriguez-Sanchez B, Medelling C, Martinez-Valle A, Läderach P (2016) Mapping climate change impacts and adaptive capacity of smallholder agricultural livelihoods in Central America: ranking and descriptive approaches to support adaptation strategies. Clim Chang. doi:10.1007/s10584-016-1792-0

Bulmer-Thomas V (1987) The political economy of Central America since 1920. Cambridge University Press, New York

Bunn C, Läderach P, Ovalle O, Kirschke D (2015) A bitter cup: climate change profile of global production of Arabica and Robusta coffee. Clim Chang 129(1-2):89-101

CATIE, CCAFS (2014) Managing climate risks to agriculture in Central America. Workshop Report. Turrialba, Costa Rica

CEPAL (2011) La economía del cambio climático en Centroamérica. Mexico D.F

DeClerck FAJ, Chazdon R, Holl KD et al (2010) Biodiversity conservation in human-modified landscapes of Mesoamerica: past, present and future. Biol Conserv 143:2301-2313. doi:10.1016/j.biocon.2010.03.026

Diro G, Rauscher S, Giorgi F (2012) Sensitivity of seasonal climate and diurnal precipitation over Central America to land and sea surface schemes in RegCM4. Clim Res 52:31-48

Donatti CI, Harvey CA, Martinez-Rodriguez MR, Vignola R, Rodriguez CM (2016) What information do policy makers need to develop climate adaptation plans for smallholder farmers? The case of Central America and Mexico. Clim Chang. doi:10.1007/s10584-016-1787-x

Eitzinger A, Läderach P, Sonder, KSchmidt A et al (2013) Tortillas on the roaster: Central America's maize-bean systems and the changing climate. CIAT Policy Brief No. 6. Cali, Colombia

Engelbrecht BMJ, Comita LS, Condit RS et al (2007) Drought sensitivity shapes species distribution patterns in tropical forests. Nature 447:80-82. doi:10.1038/nature05747

Enquist BJ, Enquist CAF (2011) Long-term change within a Neotropical forest: assessing differential functional and floristic responses to disturbance and drought. Glob Chang Biol 17:1408-1424. doi:10.1111/j.13652486.2010.02326.x

Espíndola E, León A, Martínez R, Schejtman A (2005) Poverty, hunger and food security in Central America and Panama. Santiago de Chile, Chile

Fallas B, Alfaro E (2012a) Uso de herramientas estadísticas para la predicción estacional del campo de precipitación en América Central como apoyo a los Foros Climáticos Regionales. 1: Análisis de tablas de contingencia. Rev Climatol 12:61-79

Fallas B, Alfaro E (2012b) Uso de herramientas estadísticas para la predicción estacional del campo de precipitación en América Central como apoyo a los Foros Climáticos Regionales 2:Análisis de Correlación Canónica. Rev Climatol 12:93-105

Fallas-López B, Alfaro E (2014) Predicción estacional de las temperaturas máximas y mínimas en América Central. Tópicos Meteorológicos y Ocean 13:5-26

FAO (2012) FAOSTAT. In: FAOSTAT

Fung E, Imbach P, Corales L, Vilchez S, Zamora N, Argotty F, Hannah L, Ramos Z (2016) Mapping conservation priorities and connectivity pathways under climate change for tropical ecosystems. Clim Chang. doi:10.1007/s10584-016-1789-8

García-Solera I, Ramirez P (2012) Central America's seasonal climate outlook forum

Gentry AH (1982) Neotropical floristic diversity: phytogeographical connections between Central and South America, Pleistocene climatic fluctuations, or an accident of the Andean Orogeny? Ann Mo Bot Gard 69: 557-593. doi:10.2307/2399084

Giorgi F (2006) Climate change hot-spots. Geophys Res Lett 33:1-4. doi:10.1029/2006GL025734

Guha-Sapir D, Below R, Hoyois P (2014) EM-DAT: international disaster database 
Guido Z, Rountree V, Greene C et al (2016) Connecting climate information producers and users: boundary organization, knowledge networks, and information brokers at Caribbean Climate Outlook Forums. Weather Clim Soc. doi:10.1175/WCAS-D-15-0076.1

Hannah L, Donatti CI, Harvey CA, Alfaro E, Rodriguez DA, Bouroncle C, Castellanos E, Diaz F, Fung E, Hidalgo HG, Imbach P, Läderach P, Landrum JP, Solano AL (2016a) Regional modeling of climate change impacts on smallholder agriculture and ecosystems in Central America. Clim Chang. doi:10.1007/s10584016-1867-y

Hannah L, Steele M, Imbach P, Flint L, Flint A (2016b) Climate change influences on pollinator, forest, and farm interactions across a climate gradient. Clim Chang. doi:10.1007/s10584-016-1868-X

Hastenrath S, Polzin D (2013) Climatic variations in Central America and the Caribbean. Int J Climatol 33:13481356. doi:10.1002/joc. 3515

Hernandez JL, Srikishen J, Erickson III DJE et al (2006) A regional climate study of central america using the MM5 modeling system: results and comparison to observations. 2179:2161-2179. doi:10.1002/joc

Hidalgo H, Alfaro E (2014) Skill of CMIP5 climate models in reproducing 20th century basic climate features in Central America. Int J Climatol. doi:10.1002/joc.4216

Hidalgo HG, Durán-Quesada AM, Amador JA et al (2015) The Caribbean low-level jet, the inter-tropical convergence zone and precipitation patterns in the intra-Americas Sea: a proposed dynamical mechanism. Geogr Ann Ser A Phys Geogr 97:41-59. doi:10.1111/geoa.12085

Hidalgo HG, Alfaro EJ, Quesada-Montano B (2016) Observed (1970-1999) climate variability in Central America using a high-resolution meteorological dataset with implication to climate change studies. Clim Chang. doi:10.1007/s10584-016-1786-y

Holland MB, Shamer SZ, Imach P, Zamora JC, Moreno CM, Hidalgo EJL, Donatti CI, Martinez-Rodriguez MR, Harvey CA (2016) Mapping adaptive capacity and smallholder agriculture: applying expert knowledge at the landscape scale. doi:10.1007/s10584-016-1810-2

Imbach AC (2012) Estrategias de vida: analizando las conexiones entre la satisfacción de las necesidades humanas fundamentales y los recursos de las comunidades rurales. Geolatina S.A, Turrialba

Imbach P, Molina L, Locatelli B et al (2012) Modeling Potential Equilibrium States of Vegetation and Terrestrial Water Cycle of Mesoamerica under Climate Change Scenarios. J Hydrometeorol 13:665-680. doi:10.1175 /JHM-D-11-023.1

IPCC (2013) Climate Change (2013) The Physical Science Basis. Contribution of Working Group I to the Fifth Assessment Report of the Intergovernmental Panel on Climate Change. In: Stocker TF, Qin D, Plattner G-K, et al. (eds) Cambridge University Press, United Kingdom, p 1535

Janzen DH (1987) How to grow a tropical national park: basic philosophy for Guanacaste National Park, northwestern Costa Rica. Experientia 43(9):1037-1038

Karmalkar AV, Bradley RS, Diaz HF (2011) Climate change in Central America and Mexico: Regional climate model validation and climate change projections. Clim Dyn 37:605-629. doi:10.1007/s00382-011-1099-9

Kreft S, Eckstien D (2013) Global climate risk index 2014: who suffers most from extreme weather events? Weather-related loss events in 2012 and 1993 to 2012. Bonn

Krznaric R (2006) The limits on pro-poor agricultural trade in Guatemala: land, labour and political power. J Hum Dev 7:111-135. doi:10.1080/14649880500502144

Läderach P, Haggar J P, Lau C, Eitzinger A, Ovalle O, Baca M, Jarvis A, Lundy M (2010) Mesoamerican coffee: building a climate change adaptation strategy. Centro Internacional de Agricultura Tropical (CIAT), Cali, CO. 2 p. (CIAT Policy Brief No. 2)

Läderach P, Ramirez-Villegas J, Navarro-Racines C, Zelaya C, Martinez-Valle A, Jarvis A (2016) Climate change adaptation of coffee production in space and time. Clim Chang. doi:10.1007/s10584-016-1788-9

Lawton RO, Nair US, Pielke RA, Welch RM (2001) Climatic impact of tropical lowland deforestation on nearby montane cloud forests. Science 294:584-587

Lemos MC, Kirchhoff CJ, Ramprasad V (2012) Narrowing the climate information usability gap. Nat Clim Chang 2:789-794. doi:10.1038/nclimate1614

Lyra A, Imbach P, Rodriguez D, Chou SC, Georgiou S, Gorofolo L (2016) Projections of climate change impacts on central America tropical rainforest. Clim Chang. doi:10.1007/s10584-016-1790-2

Magaña V, Amador JA, Medina S (1999) The midsummer drought over Mexico and Central America. J Clim 12: 1577-1588. doi:10.1175/1520-0442(1999)012<1577:tmdoma>2.0.co;2

Maldonado T, Alfaro E, Fallas-López B, Alvarado L (2013) Seasonal prediction of extreme precipitation events and frequency of rainy days over Costa Rica, Central America, using Canonical Correlation Analysis. Adv Geosci 33:41-52. doi:10.5194/adgeo-33-41-2013

Malhi Y, Wright J (2004) Spatial patterns and recent trends in the climate of tropical rainforest regions. Philos Trans R Soc Lond Ser B Biol Sci 359:311-329. doi:10.1098/rstb.2003.1433

Mase AS, Prokopy LS (2013) Unrealized potential: a review of perceptions and use of weather and climate information in agricultural decision making. Weather Clim Soc 47-61. doi:10.1175/WCAS-D-12-00062.1 
McSweeney K, Coomes OT (2011) Climate-related disaster opens a window of opportunity for rural poor in northeastern Honduras. Proc Natl Acad Sci U S A 108:5203-5208. doi:10.1073/pnas.1014123108

Myers N, Mittermeier RA, Mittermeier CG et al (2000) Biodiversity hotspots for conservation priorities. Nature 403:853-858. doi:10.1038/35002501

Nakaegawa T, Kitoh A, Ishizaki Y et al (2013a) Caribbean low-level jets and accompanying moisture fluxes in a global warming climate projected with CMIP3 multi-model ensemble and fine-mesh atmospheric general circulation models. Int J Climatol n/a-n/a. doi:10.1002/joc.3733

Nakaegawa T, Kitoh A, Murakami H, Kusunoki S (2013b) Annual maximum 5-day rainfall total and maximum number of consecutive dry days over Central America and the Caribbean in the late twenty-first century projected by an atmospheric general circulation model with three different horizontal resolutions. Theor Appl Climatol 1-14. doi:10.1007/s00704-013-0934-9

Neelin JD, Münnich M, Su H et al (2006) Tropical drying trends in global warming models and observations. Proc Natl Acad Sci U S A 103:6110-6115. doi:10.1073/pnas.0601798103

Nieuwolt S (1977) Tropical climatology: an introduction to the climates of the low latitudes. Wiley, New York

Oglesby R, Rowe C, Grunwaldt A et al (2016) A high-resolution modeling strategy to assess impacts of climate change for Mesoamerica and the Caribbean. Am J Clim Chang 5:202-228. doi:10.4236/ajcc.2016.52019

Olson DM, Dinerstein E, Wikramanayake ED et al (2001) Terrestrial ecoregions of the world: a new map of life on earth. Bioscience 51:933. doi:10.1641/0006-3568(2001)051[0933:TEOTWA]2.0.CO;2

Ovalle-Rivera O, Läderach P, Bunn C et al (2015) Projected shifts in Coffea arabica suitability among major global producing regions due to climate change. PLoS One 10:e0124155. doi:10.1371/journal. pone. 0124155

Pounds J, Fogden MPL, Campbell J (1999) Biological response to climate change on a tropical mountain. Nature 398:611-615. doi:10.1038/19297

Pounds J, Bustamante MR, Coloma LA et al (2006) Widespread amphibian extinctions from epidemic disease driven by global warming. Nature 439:161-167

Rauscher S, Giorgi F, Diffenbaugh N, Seth A (2008) Extension and intensification of the Meso-American midsummer drought in the twenty-first century. Clim Dyn 31:551-571

Serra YL, Kiladis GN, Hodges KI (2010) Tracking and mean structure of easterly waves over the intra-Americas Sea. J Clim 23:4823-4840. doi:10.1175/2010JCLI3223.1

Steinhoff D, Monaghan A, Clark M (2015) Projected impact of twenty-first century ENSO changes on rainfall over Central America and northwest South America from CMIP5 AOGCMs. Clim Dyn 44:1329-1349. doi:10.1007/s00382-014-2196-3

Still CJ, Foster PN, Schneider SH (1999) Simulating the effects of climate change on tropical montane cloud forests. Nature 398:608-610. doi:10.1038/19293

Stone RC, Reushle S, Reddy R (2012) Web-based'discussion-support'agricultural climate information for regional India. APN Sci Bull 55-58

Taylor MA, Alfaro EJ (2005) Climate of Central America and the Caribbean. In: Oliver J (ed) Encyclopedia of World Climatology. Springer, Netherlands, pp 183-189

Tourigny E, Jones CG (2009) An analysis of regional climate model performance over the tropical Americas. Part I: Simulating seasonal variability of precipitation associated with ENSO forcing. Tellus Ser A Dyn Meteorol Oceanogr 61:323-342. doi:10.1111/j.1600-0870.2008.00386.x

Zárate-Hernández E (2013) Climatología de masas invernales de aire frío que alcanzan Centroamérica y el Caribe y su relación con algunos índices Árticos. Tópicos Meteorológicos y Ocean 12:35-55 